\title{
Effect of Chronic Neutral Endopeptidase Inhibition on Cardiac Hypertrophy after Experimental Myocardial Infarction
}

\author{
Kazunori Yoshida, MD; Minoru Yasujima, MD*; \\ David J. Casley**; Colin I. Johnston, MD**
}

\begin{abstract}
Candoxatril is an inhibitor of neutral endopeptidase, a membrane-bound enzyme that degrades atrial natriuretic peptide. The effects of candoxatril on hemodynamic parameters and cardiovascular hypertrophy were evaluated in the rat model of myocardial infarction. Myocardial infarction was induced by left coronary artery ligation in rats and they were treated either with candoxatril $(10 \mathrm{mg} / \mathrm{kg}$ per day) or a vehicle for up to 4 weeks. Systolic blood pressure and body weight did not change for up to 4 weeks between the 2 groups. At the end of treatment, hemodynamic parameters were measured, and then plasma, heart, lungs and kidneys were collected. Kidney neutral endopeptidase, as measured by the quantitative autoradiographic method, was significantly inhibited in candoxatril-treated rats compared with that in controls $(66.6 \pm 3.2 \%$ of control, $\mathrm{p}<0.001)$. On the contrary, there were no significant differences in right atrial pressure, left ventricular end-diastolic pressure, systemic pressure, and plasma level of atrial natriuretic peptide between the 2 groups. There were also no significant differences in cardiac weight and lung weight. These data indicate that inhibition of neutral endopeptidase by candoxatril at a dose of $10 \mathrm{mg} / \mathrm{kg}$ per day did not oppose cardiac hypertrophy in the rat model of myocardial infarction in spite of significant neutral endopeptidase inhibition. (Jpn Circ J 1998; 62: 680-686)
\end{abstract}

Key Words: Autoradiography; Candoxatril; Cardiac hypertrophy; Myocardial infarction; Neutral endopeptidase

$\mathbf{C}$ ongestive heart failure carries a grave prognosis, with a mortality rate of over $50 \%$ within 5 years of diagnosis $!^{1,2}$ The progressive nature of the disease is due in part to a series of neurohumoral homeostatic responses that initially maintain cardiac output and tissue perfusion but ultimately prove deleterious by increasing cardiac work and further reducing cardiac function 3,4 These responses include enhancement of sympathetic tone, alteration in regional vascular resistance, activation of the renin-angiotensin-aldosterone system, and sodium retention.

Atrial natriuretic peptide (ANP) is a peptide hormone of cardiac origin with multiple biologic effects including diuresis, natriuresis, vasodilatation, and inhibition of renin and aldosterone secretion,5,6 Based on these properties, some studies have suggested a therapeutic role for ANP in congestive heart failure $7{ }^{8}$ However, the therapeutic potential of ANP is limited by its peptidic nature and rapid elimination from circulation. Long-term therapy requires either an orally active analogue or an inhibitor of ANP metabo-

(Received February 12, 1998; revised manuscript received April 9, 1998; accepted April 27, 1998)

Section of Internal Medicine and Disability Prevention, Disability Science, Tohoku University Graduate School of Medicine, Sendai, Japan, *Department of Laboratory Medicine, Hirosaki University School of Medicine, Hirosaki, Japan, and **Department of Medicine, University of Melbourne, Austin and Repatriation Medical Center, Heidelberg, Victoria, Australia

Sponsorship: This work was supported by grants from the Austin Hospital Research Foundation and the National Heart Foundation of Australia

Mailing address: Kazunori Yoshida MD, Section of Internal Medicine and Disability Prevention, Disability Science, Tohoku University Graduate School of Medicine, Sendai 980-8574, Japan lism. Neutral endopeptidase (NEP) is a major ANP-degrading enzyme,-11 and a new therapeutic approach has been developed by inhibiting the enzyme and potentiating the effects of endogenous ANP! ${ }^{12-15}$ Beneficial acute hemodynamic and renal effects of ( \pm )-candoxatrilat (UK69578), an NEP inhibitor, have been reported in patients with congestive heart failure!2,13 Furthermore, reports about the effects of NEP inhibitors on cardiovascular remodeling have been published recently! 6,17

In patients with myocardial infarction, progressive left ventricular dilatation begins soon after myocardial infarction $^{18}$ and left ventricular volume is the most powerful predictor of prognosis 19,20 In the rat model of chronic heart failure with coronary ligation, a time-dependent increase in ventricular volume was attenuated by chronic therapy with captopril, an angiotensin converting enzyme (ACE) inhibitor ${ }^{21}$ and, moreover, therapy with captopril had a pronounced effect on survival?2 2 The aim of this study was to examine whether chronic treatment with the NEP inhibitor candoxatril (UK79300) would modify cardiac hypertrophy in the rat model of myocardial infarction. Candoxatril is an orally active indanyl ester prodrug of the compound candoxatrilat (UK73967), the active isomer of the racemic mixture known as $( \pm)$-candoxatrilat (UK69578)!2,13

\section{Methods}

Adult male Sprague-Dawley rats (Biological Research Laboratories, Austin Hospital, Victoria, Australia) weighing about $300 \mathrm{~g}$ were used for this study. These animal studies conformed to the guiding principles of the NHMRC/CSIRO code of conduct and were approved by 
the Austin Hospital Animal Ethics Research Committee.

\section{Experimental Myocardial Infarction}

Myocardial infarction was induced by left coronary artery ligation using the method of Pfeffer et $\mathrm{al}_{2}^{21,22}$ and this method is well established in our laboratory?23,24 Briefly, rats were anesthetised with ether, intubated and then ventilated using a small rodent respirator. Anesthesia was maintained by a mixture of oxygen and enflurane. A left thoracotomy was performed, the heart exteriorized, and a 6-0 Prolene ligature placed between the pulmonary artery outflow tract and the left atrium. The heart was returned to the normal position, then the lungs were reinflated using positive end-expiratory pressure. The ribs were pulled together with 3-0 silk, and muscles and skin were sutured separately by $3-0$ silk. Thoracotomy without left coronary artery ligation was performed on sham-operated rats $(n=6)$. After surgery the rats were allowed free access to tap water and a normal diet containing $20 \%$ protein, $0.8 \%$ potassium, and $0.3 \%$ sodium by weight (Clark King \& Co, Melbourne, Victoria, Australia).

\section{Treatment}

One week after coronary ligation or sham-operation, the rats were weighed and systolic blood pressure was measured by the tail-cuff method with preheating. Then the rats with coronary ligation were assigned to one of two treatments. The first group received $10 \mathrm{mmol} / \mathrm{L}$ TRIS (Sigma Chemical Co, St Louis, MO, USA) as drinking fluid (control group), and the second group received candoxatril dissolved in $10 \mathrm{mmol} / \mathrm{L}$ TRIS as drinking fluid. Body weight was measured weekly and the concentration of candoxatril in the drinking fluid was adjusted weekly to a daily dose of $10 \mathrm{mg} / \mathrm{kg}$ per day. Sham-operated rats received $10 \mathrm{mmol} / \mathrm{L}$ TRIS as drinking fluid. The treatment was continued for 4 weeks.

\section{Hemodynamic Measurement and Organ Preparation}

Systolic blood pressure was measured weekly by the tail-cuff method with preheating during the experimental period. At the end of the 4-week treatment period, by which time the necrotic myocardium had been completely replaced by fibrous scar tissue ${ }^{25}$ rats were anesthetised and placed on a temperature-controlled table $\left(37^{\circ} \mathrm{C}\right)$ for hemodynamic measurement. Anesthesia was induced by ether, then maintained with oxygen and $2 \%$ enflurane mixture under spontaneous respiration. The right carotid artery and the right jugular vein were cannulated with a polyethlene tube (PE-30). The catheters were connected via a stop cock to a Statham transducer (Model P23 G6), and pressure was recorded on a polygraph (Neotrace $400 \mathrm{ZEF}$, Neomedix System, Victoria, Australia). The arterial and venous catheters were then advanced into the left ventricle and right atrium, respectively, and were then withdrawn to the aorta and superior vena cava for recording of phasic and mean left ventricular, ascending aortic and right atrial pressure and heart rate. After hemodynamic measurement, blood was drawn from the arterial catheter for hormonal measurement. The rats were then killed by decapitation for organ collection.

The heart and lungs were removed, washed in saline, and weighed. The cardiac chambers were then individually dissected, separated, and weighed. Organ weights were corrected for body weight. Infarct size was determined by planimetry and expressed as the percentage of fibrous scar to total left ventricular circumference 23,24 The kidneys were rapidly removed, washed in saline, snap-frozen in isopentane at $-40^{\circ} \mathrm{C}$, and used for autoradiographic localization of NEP.

\section{In Vitro Autoradiography of NEP}

Serial frozen sections $(20 \mu \mathrm{m})$ of the kidney were cut in a cryostat maintained at $-20^{\circ} \mathrm{C}$, thaw-mounted on gelatincoated glass slides, dried in a desiccator for $2 \mathrm{~h}$ at $4^{\circ} \mathrm{C}$, and then stored at $-80^{\circ} \mathrm{C}$ until use. SCH47896 (ScheringPlough Research, NJ, USA) was radioiodinated using ${ }^{125} \mathrm{I}$ and an iodogen (Pierce Chemicals Co, Rochford, ILL, USA) as mentioned previously ${ }^{26} \mathrm{SCH} 47896$ is a phenolic analogue of SCH39370 and is a suitable substrate for iodination. SCH48446, the di-iodo analogue of SCH47896, is the major product of iodination and also an excellent inhibitor of NEP, with potency comparable to that of SCH3937026 The sections were incubated by a modification of the previously reported technique ${ }^{26}$ All sections were warmed to $20^{\circ} \mathrm{C}$ just before incubation. The sections were incubated with approximately $0.2 \mathrm{nmol} / \mathrm{L}(500000$ $\mathrm{cpm} / \mathrm{ml}$ ) of ${ }^{125} \mathrm{I}-\mathrm{SCH} 47896$ in $150 \mu 1$ of $10 \mathrm{mmol} / \mathrm{L}$ $\mathrm{Na} 2 \mathrm{HPO} 4$ buffer, $\mathrm{pH} 7.4$, containing $150 \mathrm{mmol} / \mathrm{L} \mathrm{NaCl}$ and $0.2 \%$ bovine serum albumin (CIS Ltd, Victoria, Australia) for $40 \mathrm{~min}$ at $20^{\circ} \mathrm{C}$. Nonspecific binding was determined in the presence of 10 $\mathrm{mol} / \mathrm{L} \mathrm{SCH} 39370$ (Schering-Plough Research). After incubation, the slide-mounted sections were transferred through four successive 1-min washes of $10 \mathrm{mmol} / \mathrm{L} \mathrm{Na} \mathrm{HPO}_{4}$ buffer ( $\mathrm{pH} 7.4$ ), containing 150 $\mathrm{mmol} / \mathrm{L} \mathrm{NaCl}$, at $0^{\circ} \mathrm{C}$. The slides were then rapidly dried under a stream of cold air, loaded in X-ray cassettes, and exposed to Agfa Scopix X-ray film (Agfa Gevaert, Australia) for 5 days at room temperature. The X-ray films were processed in a Kodak RPX-OMAT automatic developer, and optical density was quantitated by computerized densitometry using an Eye Com Model 850 image analysis system (Spatial Data System, Springfield, VA, USA) coupled to a DEC 11/23 LSI computer (Digital Equipment Corp, Maynard, MA, USA). Standards of 125 I radioactivity were applied to $5-\mathrm{mm}$ diameter discs of $20 \mu \mathrm{m}$ rat brain sections and mounted on slides. One set of the radioactivity standards was exposed to the same film in parallel with the tissue sections. These standards were fitted to a calibration curve by computer to convert optical density values of each pixel into $\mathrm{dpm} / \mathrm{mm}^{2}$. Four sections of each rat were incubated for total binding, and 2 sections of each rat were incubated for nonspecific binding. Specific binding for each rat was calculated as the average of total binding minus nonspecific binding.

\section{Plasma ANP Measurement}

Plasma ANP (determined as immunoreactive atrial natriuretic factor) was measured by a modified method of the previously reported technique, without extraction? ${ }^{23}$ Briefly, blood samples were put into plastic tubes containing the following inhibitors: disodium-EDTA (EDTA-Na2, AJAX Chemicals Ltd, Sydney, NSW, Australia; $1 \mathrm{mg} / \mathrm{ml}$ ), aprotinin (Sigma Chemical Co; $100 \mathrm{KIU} / \mathrm{ml}$ ), and soy bean trypsin inhibitor (SBTI, Sigma Chemical Co; 50 $\mathrm{BAEE} / \mathrm{ml}$ ). Plasma was separated by centrifugation at 3000 rpm for $15 \mathrm{~min}$ at $4{ }^{\circ} \mathrm{C}$ and stored at $-70^{\circ} \mathrm{C}$ until assay. A phosphate buffer $(100 \mathrm{mmol} / \mathrm{L}), \mathrm{pH} 7.4$, containing $0.1 \%$ bovine serum albumin, aprotinin $(500 \mathrm{KIU} / \mathrm{ml})$, SBTI $(50$ BAEE/ml), 0.1\% TritonX-100 (Packard Inst, Downers Grove, ILL, USA), EDTA-Na2 $(10 \mathrm{mmol} / \mathrm{L})$, and $0.1 \%$ 
Table 1 Effects of 4 Weeks of Treatment on Hemodynamic Parameters in Sham-Operated Rats and Rats With Myocardial Infarction

\begin{tabular}{lcccccccc}
\hline \hline & $n$ & $\begin{array}{c}H R \\
(\text { beats } / \text { min })\end{array}$ & $\begin{array}{c}S B P \\
(\mathrm{mmHg})\end{array}$ & $\begin{array}{c}M B P \\
(\mathrm{mmHg})\end{array}$ & $\begin{array}{c}\text { DBP } \\
(\mathrm{mmHg})\end{array}$ & $\begin{array}{c}\text { LVSP } \\
(\mathrm{mmHg})\end{array}$ & $\begin{array}{c}\text { LVEDP } \\
(\mathrm{mmHg})\end{array}$ & $\begin{array}{c}\text { RAP } \\
(\mathrm{mmHg})\end{array}$ \\
\hline Sham & 6 & $320.0 \pm 5.8$ & $114.4 \pm 4.0$ & $93.3 \pm 2.7$ & $79.0 \pm 2.0$ & $122.7 \pm 3.0$ & $5.8 \pm 0.7$ & $1.0 \pm 0.1$ \\
Control & 6 & $316.0 \pm 5.7$ & $110.7 \pm 3.6$ & $92.7 \pm 3.5$ & $79.7 \pm 3.6$ & $120.3 \pm 1.9$ & $11.7 \pm 1.3^{\dagger}$ & $2.6 \pm 0.5^{*}$ \\
Candoxatril & 7 & $348.6 \pm 9.7^{*}$ & $112.6 \pm 1.7$ & $98.6 \pm 1.6$ & $82.7 \pm 1.8$ & $124.6 \pm 1.9$ & $12.9 \pm 1.1^{\dagger}$ & $2.9 \pm 0.5^{*}$ \\
\hline
\end{tabular}

Values are expressed as means \pm SEM. Sham, sham-operated rats; Control, vehicle-treated rats with myocardial infarction; Candoxatril, candoxatril-treated rats with myocardial infarction; $H R$, heart rate; SBP, systolic blood pressure; MBP, mean blood pressure; DBP, diastolic blood pressure; LVSP, left ventricular systolic pressure; LVEDP, left ventricular end-diastolic pressure; $R A P$, right atrial pressure. ${ }^{*} p<0.05,{ }^{*} p<0.01$ compared with sham, ${ }^{*} p<0.05$ compared with control.

A

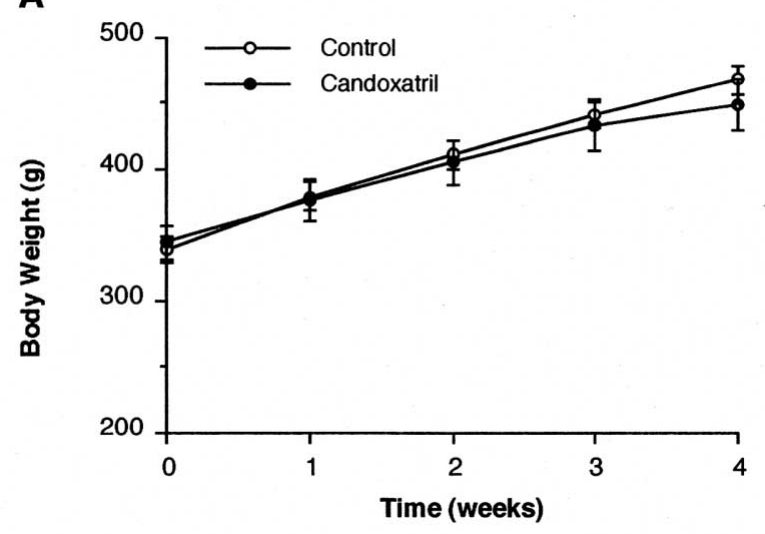

B

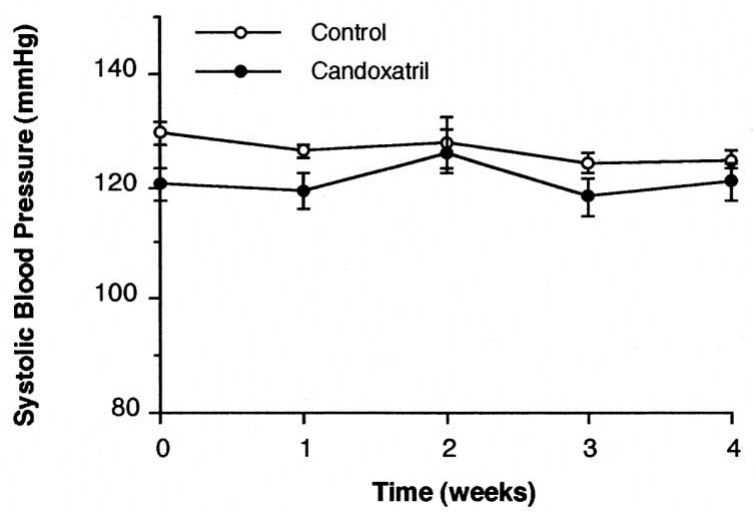

Fig 1. Line graphs showing the sequential value for body weight (panel A) and systolic blood pressure (panel B) for vehicle-treated control rats and candoxatril-treated rats. There were no statistically significant differences in body weight and systolic blood pressure between the 2 groups during the experimental period.

sodium azide, was used to dissolve all reagents and to perform the radioimmunoassay. Fifty microliters of a standard solution of synthetic a-human ANP (Peninsula Laboratories Inc, CA, USA) or plasma samples was incubated for $24 \mathrm{~h}$ at $4{ }^{\circ} \mathrm{C}$ with $150 \mu \mathrm{l}$ of buffer and $100 \mu \mathrm{l}$ of antiserum (1:75,000, sheep anti-a -human ANP). Then 100 $\mu 1$ of ${ }^{125}$ I-labeled ANP (approx. 5,500 cpm) and $300 \mu 1$ of buffer were added and incubated for $16 \mathrm{~h}$. The separation of antibody-bound and free peptides was performed using goat anti-sheep Y -globulin in the presence of normal sheep plasma. The anti-a -human ANP antibody was directed against the $\mathrm{COOH}$-terminal portion of ANP and cross-
A
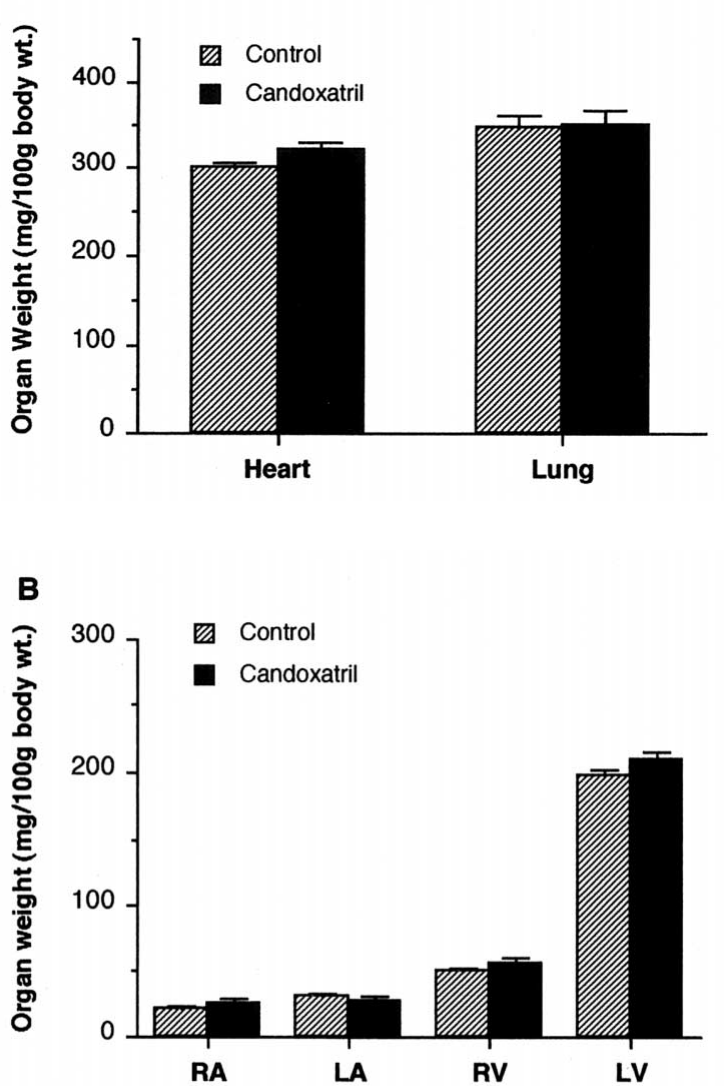

Fig 2. Bar graphs showing total heart weight and lung weight (panel A) and 4 cardiac chamber weight (panel B) for vehicle-treated control rats and candoxatril-treated rats. RA, right atrium; LA, left atrium; $\mathrm{RV}$, right ventricle; LV, left ventricle. Values are expressed as $\mathrm{mg} / 100 \mathrm{~g}$ body weight. There was no statistically significant difference in any of the parameters between the 2 groups.

reacted $100 \%$ with a -rat ANP.

\section{Statistics}

Data are shown as mean \pm SEM. The values were analyzed by analysis of variance, and significant difference was determined by the multiple comparison test (Scheffé test). Statistical significance was defined as $\mathrm{p}<0.05$.

\section{Results}

After surgery, 10 of the original 30 rats with coronary artery ligation died within 1 week, and most of these 10 
rats died within $24 \mathrm{~h}$ after surgery. Two vehicle-treated rats and one candoxatril-treated rat died during the subsequent 4-week treatment period, and these rats were excluded from analysis. Two vehicle-treated rats and 2 candoxatriltreated rats did not have any apparent myocardial infarction at the end of the experiment. These rats were also excluded from analysis. All sham-operated rats survived through the experimental period.

\section{Comparison Between Infarct Rats and Sham-Operated Rats}

There were no significant differences in body weight and systolic blood pressure during the study period between control infarct rats and sham-operated rats (data not shown). Control infarct rats had a higher heart weight $(301.2 \pm 4.9$ vs $288.3 \pm 1.0 \mathrm{mg} / 100 \mathrm{~g}$ body weight, $\mathrm{p}<0.05)$ and a higher plasma ANP level (507.5 \pm 102.3 vs $187.3 \pm 13.4 \mathrm{pg} / \mathrm{ml}, \mathrm{p}<0.05)$ compared with the sham-operated rats. Hemodynamic measurements demonstrated that control infarct rats had higher left ventricular end-diastolic pressure (LVEDP) and higher right atrial pressure (RAP) than those of the sham-operated rats (Table 1).

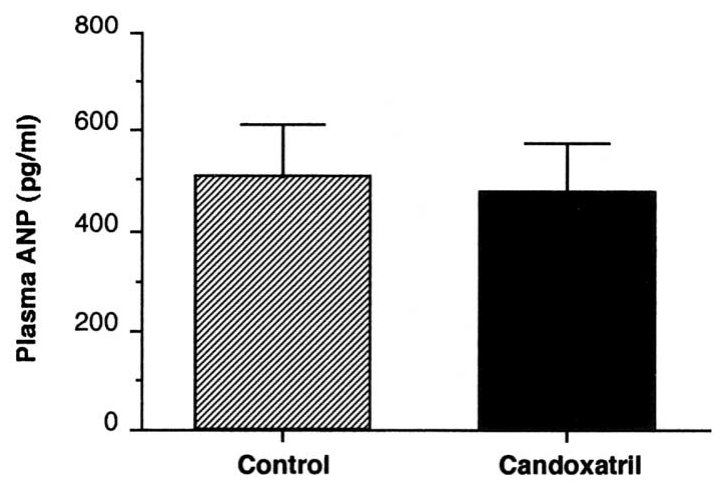

Fig 3. Plasma atrial natriuretic peptide (ANP) concentration determined as immunoreactive atrial natriuretic factor in vehicle-treated control rats and candoxatril-treated rats. Both groups showed high ANP concentration, but there was no significant difference between the groups.

\section{Effects of Chronic Candoxatril Treatment in Rats With Infarction}

There was no significant difference in the mean infarct size between vehicle-treated control rats $(n=6,30.2 \pm 4.2 \%)$ and candoxatril-treated rats $(n=7,33.7 \pm 5.1 \%)$. Body weight change during the experimental period is shown in Fig 1A. There was no significant difference in basal body weight between the 2 groups. Treatment with candoxatril induced no significant difference in body weight gain compared with vehicle treatment for up to 4 weeks. Systolic blood pressures of the 2 groups are shown in Fig 1B. There was no significant difference in systolic blood pressure between the 2 groups at the beginning of treatment. Again, treatment with candoxatril induced no significant difference in blood pressure compared with controls during the experimental period. Table 1 shows hemodynamic parameters at the end of treatment. Candoxatril-treated rats had a higher heart rate compared with control infarct rats and sham-operated rats. LVEDP and RAP of candoxatril-treated rats were higher than those of sham-operated rats, but they were not significantly different from those of control infarct rats. Fig 2 shows the total heart weight and lung weight (panel A) and the four cardiac chamber weight (panel B) of the 2 groups. There were no significant differences in total heart weight and lung weight or in four cardiac chamber weights between the controls and candoxatril-treated rats. Fig 3 shows the plasma ANP concentrations of the 2 groups. There was no significant difference in the plasma ANP level between the 2 groups. Autoradiographic visualization of NEP in the kidney is shown in Fig 4. Nonspecific binding was less than $10 \%$ of total binding in control rats, and there was no significant difference in nonspecific binding between the 2 groups. Thus, only pictures of total binding are shown in the Figure. In control rats, ${ }^{125} \mathrm{I}-\mathrm{SCH} 47896$ bound to regions of the outer stripe of the outer medulla and to the inner cortex, consistent with binding to the deep proximal tubules. There was no binding detectable in the glomeruli. NEP binding in the kidney was markedly inhibited by candoxatril treatment. Fig 5 shows quantitative values of NEP binding obtained from computer analysis. NEP activity in candoxatril-treated rats was $66.6 \pm 3.2 \%$ of the control

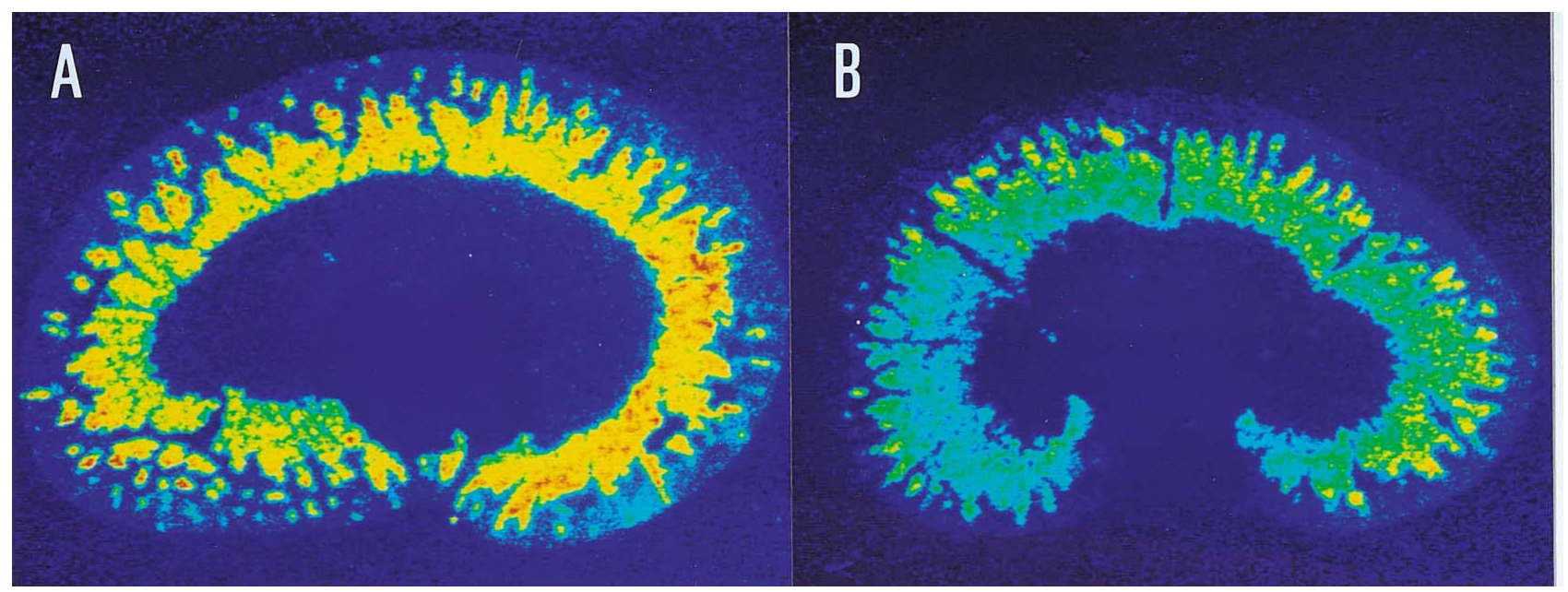

Fig 4. Computer-generated pseudo-color image of autoradiographs of ${ }^{125} \mathrm{I}-\mathrm{SCH} 47896$ binding to rat kidney. Panel A: section from vehicle-treated control rat. Panel B: section from candoxatril-treated rat. Red represents high levels of binding and blue represents low-to-undetectable levels of binding. High densities of binding sites are seen in the outer stripe of the outer medulla and in the inner cortex. Note the marked suppression of binding sites in the candoxatril-treated rat. 


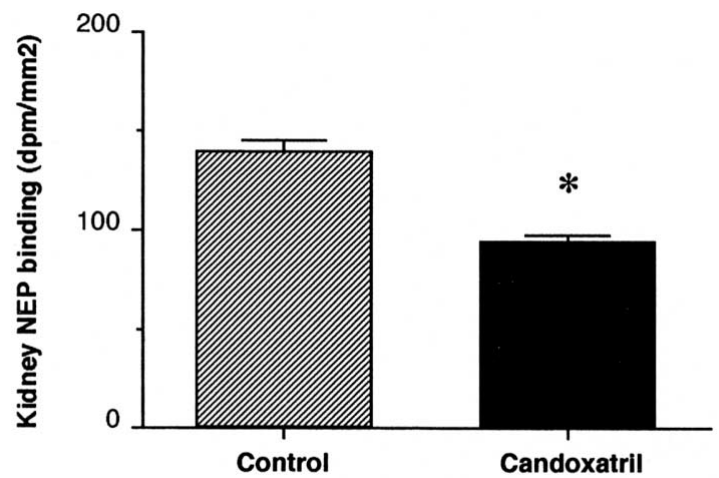

Fig 5. Quantitative value of kidney neutral endopeptidase (NEP) binding obtained from computer analysis. NEP binding in candoxatril-treated rats was significantly inhibited compared with that in control rats. ${ }^{*} \mathrm{p}<0.001$ vs control.

rats $(\mathrm{p}<0.001)$.

\section{Discussion}

In our present experiment, chronic candoxatril treatment of rats with myocardial infarction failed to exert any significant changes in hemodynamic parameters other than heart rate or any significant changes in heart weight and lung weight (or in other words, lung congestion). As NEP is most prominent in brush border vesicles of proximal tubular cells, ${ }^{9-11}$ we measured kidney NEP by the quantitative autoradiographic method in the present study. Kidney NEP binding in candoxatril-treated rats was significantly inhibited compared with that in vehicle-treated rats.

As far as we know, there are only 3 reports concerning the effects of chronic NEP inhibition on cardiac hypertrophy in rats with myocardial infarction. One of these reports is on the effects of 4 weeks of treatment with TM1, a prodrug of the NEP inhibitor SQ2860327 and the other 2 reports describe the effects of 4 weeks of treatment with alatriopril or aladotril, mixed inhibitors of NEP and ACE28,29 Treatment with TM1 reduced the development of right ventricular and atrial hypertrophy but had no effect on the left ventricle and septum weights 27 Alatriopril showed a greater potency than captopril in reducing cardiac hypertrophy, suggesting that enhancement of ANP levels via NEP inhibition magnifies the capacity of ACE inhibition to prevent cardiac hypertrophy ${ }^{28}$ Aladotril decreased LVEDP to approximately the same extent as captopril and reduced cardiac hypertrophy without any hypotensive effect ${ }^{29}$

In the present study, we examined the effects of only one dose of candoxatril. In our preliminary experiment using quantitative in vitro autoradiography, a single gavage of candoxatril at a dose of $10 \mathrm{mg} / \mathrm{kg}$ inhibited kidney NEP binding to $13 \%$ of that of the controls at $1 \mathrm{~h}$, and this inhibition was significant for up to $24 \mathrm{~h}$. As demonstrated in the present study by quantitative in vitro autoradiography, NEP binding was significantly inhibited compared with that of the controls, even after the chronic 4-week treatment period. Although the plasma ANP level of candoxatriltreated rats was not significantly different from that in controls, reports about the relationship between the effects of NEP inhibition and plasma ANP level are not consistent. In some reports, effects of NEP inhibition were in parallel with the elevation of plasma ANP level ${ }^{12,15}$ while in other reports, NEP inhibitors exerted effects without any change in the plasma ANP level 30,31 or their effects did not parallel increases in plasma ANP32 In the present experiment, candoxatril was administered to the rats by dissolving it in drinking water. This method might have caused the difference in the relationship among plasma ANP level, kidney NEP binding and cardiovascular actions, because in most studies, NEP inhibitors were administered using a bolus method. Helin et al reported that following injection of SCH39370 in rats with heart failure and in the controls, diuresis tended to increase during the first $6 \mathrm{~h}$ and then decreased significantly during the next $6 \mathrm{~h} !^{14}$ Electrolyte excretion also decreased significantly during the latter $6 \mathrm{~h}$ in SCH39370-treated rats. The administration of candoxatril to rats by dissolving it in drinking water may have resulted in a distinct pattern of hemodynamic and renal effects. Because rats drink more water during the night, significant cardiorenal action might have occurred during the night and significantly decreased diuresis and natriuresis due to rebound occurring during the daytime. However, this is not clear from our study because we did not complete a metabolic study. It remains to be examined whether higher doses of candoxatril and structurally different NEP inhibitors may oppose cardiac hypertrophy after myocardial infarction or not.

Degradation of ANP by NEP would block the potential effect of plasma-derived peptides on renal function. The presence of NEP on the brush border on the proximal tubules and its inhibition by NEP inhibitors may allow delivery of intact filtered ANP to ANP receptor sites on the inner medullary collecting duct 33,34 However, as demonstrated by Tsunoda et al, ANP binding sites of the inner medulla in rats with chronic heart failure are reduced 23 It is not clear whether these binding sites are type-A receptors (NPR-A) or type-C receptors (NPR-C), because both types of receptor bind ANP with high affinity 35,36 By in vivo microperfusion of the inner medullary collecting duct in rats, Sonnenberg et al showed that administration of ANP intraluminally resulted in reduced sodium efflux or decreased sodium reabsorption 37 This observation suggests the possibility that ANP receptors are located on the luminal site. If luminal receptors for ANP are present, they would not be expected to downregulate in heart failure, because they would not be exposed to the high circulatory levels of ANP. Therefore, the putative intraluminal ANP receptors would maintain responsiveness to any ANP protected by NEP inhibition. If intraluminal receptors for ANP in the inner medullary collecting duct are exposed to a high concentration of ANP by chronic NEP inhibition, then it is possible that these receptors might be downregulated during long-term NEP inhibition.

Short-term beneficial cardiovascular and renal effects of NEP inhibition have been reported in humans and in animals. On the other hand, Richards et al demonstrated differences between acute and chronic studies. In their chronic study, they administered candoxatril to normal volunteers over a period of 4 days 30 This treatment caused a range of effects that differed from those documented in single-dose studies using similar subjects studied under similar controlled conditions $3^{38}$ Similar phenomena, including lack of a significant increase in plasma ANP level, 30 might occur in a model of myocardial infarction, probably due to changes in the interaction between ANP and its receptors.

ANP is not the sole vasoactive substrate for NEP. Others include angiotensin I and II, bradykinin, substance P, big 
endothelin and endothelin $3^{39-41}$ Richards et al reported that inhibition of NEP significantly reduced clearance of infused angiotensin II (Ang II) in association with enhanced pressor response to exogenous Ang II 42 Abassi et al reported that inhibition of NEP by SQ29072 increased the urinary excretion of endothelin (ET) and plasma concentration of ET, and they also demonstrated that a similar NEP inhibitor, SQ28603, increased the urinary excretion of ET and increased the accumulation of exogenous ET in the lung and kidney ${ }^{43}$ Many reports support the importance of the cardiac renin-angiotensin system in the pathophysiology of cardiac remodeling.12,22 The role of ET in the pathophysiology of chronic congestive heart failure is now supported by reports of its plasma level elevation in human and experimental heart failure models ${ }^{44}$ The longterm effects of ET activation, including the peptide's action as a growth factor, which may contribute to cardiovascular remodeling, may become excessive and may account for a continuing deterioration in cardiac function. Therefore, the net hemodynamic and structural effects of NEP inhibition may be dependent on the proportional effects of vasopressor and vasodepressor substrates or growth promoter and growth inhibitor substrates. Raised levels of substrates other than ANP may counteract any favorable cardiovascular effects of increased plasma and tissue level ANP.

In summary, chronic treatment with candoxatril in a rat model of myocardial infarction significantly inhibited tissue NEP activity but it did not exert any favorable changes in hemodynamic parameters or in heart and lung weights. Although many reports have shown that NEP inhibition potentiates the action of ANP, other substrates for NEP might be potentiated simultaneously. Interaction among these substrates and perhaps modulation at receptor sites might have caused the present results. Further study is needed to elucidate the effects of chronic NEP inhibition on cardiac hypertrophy after myocardial infarction.

\section{Acknowledgments}

The authors are very grateful to Pfizer Central Research for supplying candoxatril, and to Schering-Plough Research for supplying SCH47896 and $S C H 39370$.

\section{References}

1. Mckee PA, Castelli WP, McNamara PM, Kannel WB: The natural history of congestive heart failure: The Framingham study. $N$ Engl $J$ Med 1971; 285: 1441-1446

2. Franciosa JA, Wilen M, Ziesche S, Cohn JN: Survival in men with severe chronic left ventricular failure due to either coronary heart disease or idiopathic dilated cardiomyopathy. Am J Cardiol 1983; 5: $831-836$

3. Cohn JN, Levine TB, Francis GS, Goldsmith S: Neurohumoral control mechanisms in congestive heart failure. Am Heart J 1981; 102: $509-514$

4. Francis GS: Neurohumoral mechanisms involved in congestive heart failure. Am J Cardiol 1985; 55: 15-21A

5. Needleman P, Greenwald JE: Atriopeptin: A cardiac hormone intimately involved in fluid, electrolyte and blood pressure homeostasis. N Engl J Med 1986; 314: 828-834

6. Lang RE, Unger T, Ganten D: Atrial natriuretic peptide: a new factor in blood pressure control. J Hypertens 1987; 5: 255-271

7. Cody RJ, Atlas SA, Laragh JH, Kubo SH, Covit AB, Ryman KS, et al: Atrial natriuretic factor in normal subject and heart failure patients. J Clin Invest 1986; 787: 1362-1374

8. Saito Y, Nakao K, Nishimura K, Sugawara A, Okumura K, Obata K, et al: Clinical application of atrial natriuretic polypeptide in patients with congestive heart failure: Beneficial effect on left ventricular function. Circulation 1987; 76: 115-124

9. Olins GM, Spear KL, Siegel NR, Zurcher-Neely HA: Inactivation of atrial natriuretic factor by the renal brush border. Biochim Biophys
Acta 1987; 901: 97-100

10. Stephenson SL, Kenny AJ: The hydrolysis of a-human atrial natriuretic peptide by pig kidney microvillar membranes is initiated by endopeptidase-24.11. Biochem J 1987; 243: $183-187$

11. Sonnenberg JL, Sakane Y, Jeng AY, Koehn JA, Ansell JA, Wennogle LP, et al: Identification of protease 3.4.24.11 as the major atrial natriuretic factor degrading enzyme in the rat kidney. Peptide 1988; 9: $173-180$

12. Northridge DB, Jardine AG, Alabaster CT, Barclay PL, Connell JMC, Dargie HJ, et al: Effect of UK69578: A novel atriopeptidase inhibitor. Lancet 1989; 2: 591-593

13. Northridge DB, Jardine AG, Findlay IN, Archibald M, Dilly SG, Dargie HJ: Inhibition of the metabolism of atrial natriuretic factor causes diuresis and natriuresis in chronic heart failure. Am J Hypertens 1990; 3: 682-687

14. Helin K, Tikkanen I, Tikkanen T, Saijonmaa O, Sybertz EJ, Vemulapalli $S$, et al: Prolonged neutral endopeptidase inhibition in heart failure. Eur J Pharmacol 1991; 198: 23-30

15. Fitzpatrick MA, Rademaker MT, Charles CJ, Yandle TG, Espiner EA, Ikram H, et al: Acute hemodynamic, hormonal, and renal effects of neutral endopeptidase inhibition in ovine heart failure. $J$ Cardiovasc Pharmacol 1992; 19: 635-640

16. Winter RJD, Zhao L, Krausz T, Hughes JMB: Neutral endopeptidase 24.11 inhibition reduces pulmonary vascular remodeling in rats exposed to chronic hypoxia. Am Rev Respir Dis 1991; 144: $1342-$ 1346

17. Monopoli A, Ongini E, Cigola E, Olivetti G: The neutral endopeptidase inhibitor, SCH34826, reduces left ventricular hypertrophy in spontaneously hypertensive rats. J Cardiovasc Pharmacol 1992; 20: 496-504

18. Eaton LW, Weiss JL, Bulkley BH, Garrison JB, Weisfeld ML: Regional cardiac dilatation after acute myocardial infarction: recognition by two-dimensional echocardiography. $N$ Engl J Med 1979; 300: $57-62$

19. Hammermeister KE, DeRouen TA, Dodge HT: Variables predictive of survival in patients with coronary disease: selection by univariate and multivariate analyses from the clinical, electrocardiographic, exercise, arteriographic, and quantitative angiographic evaluations. Circulation 1979; 59: 421-430

20. White HD, Norris RM, Brown MA, Brandt PWY, Whitlock RML, Wild CJ: Left ventricular end-systolic volume as the major determinant of survival after recovery from myocardial infarction. Circulation 1987; 76: 44-51

21. Pfeffer JM, Pfeffer MA, Braunwald E: Influence of chronic captopril therapy on the infarcted left ventricle of the rat. Circ Res 1985; 57: $84-95$

22. Pfeffer MA, Pfeffer JM, Steinberg C, Finn P: Survival after an experimental myocardial infarction: beneficial effects of long-term therapy with captopril. Circulation 1985; 72: 406-412

23. Tsunoda K, Mendelsohn FAO, Sexton PM, Chai SY, Hodsman GP, Johnston CI: Decreased atrial natriuretic peptide binding in renal medulla in rats with chronic heart failure. Circ Res 1988; 62: 155161

24. Kohzuki M, Kanazawa M, Yoshida K, Kamimoto M, Xue-Min Wu, Zhong-Li Jiang, et al: Cardiac angiotensin converting enzyme and endothelin receptor in rats with chronic myocardial infarction. Jpn Circ J 1996; 60: $972-980$

25. Fishbein MC, Maclean D, Maroko PR: Experimental myocardial infarction in rat. Am J Pathol 1978; 90: 57-70

26. Kanazawa M, Casley DJ, Sybertz EJ, Haslanger MF, Johnston CI: Localization and characterization of neutral metalloendopeptidase (EC3. 4. 24. 11), the degradative enzyme for atrial natriuretic peptide, in rat kidney using a radioiodinated neutral metalloendopeptidase inhibitor. J Pharmacol Exp Ther 1992; 261: 1231-1237

27. Marie C, Mossiat C, Gros C, Monteil T, Bralet J: Effect of prolonged inhibition of neutral endopeptidase on cardiac hypertrophy in rats with myocardial infarction. Cardiovasc Drugs Ther 1996; 10: $593-$ 598

28. Bralet J, Marie C, Mossiat C, Lecomte JM, Gros C, Schwartz JC: Effects of alatriopril, a mixed inhibitor of atriopeptidase and angiotensin I-converting enzyme, on cardiac hypertrophy and hormonal responses in rats with myocardial infarction. J Pharmacol Exp Ther 1994; 270: 8-14

29. Marie C, Mossiat C, Lecomte JM, Schwartz JC, Bralet J: Hemodynamic effects of acute and chronic treatment with aladotril, a mixed inhibitor of neutral endopeptidase and angiotensin I-converting enzyme, in conscious rats with myocardial infarction. $J$ Pharmacol Exp Ther 1995; 275: 1324-1331

30. Richards AM, Wittert G, Espiner EA, Yandle TG, Frampton C, Ikram H: Prolonged inhibition of endopeptidase 24.11 in normal 
man: renal, endocrine and haemodynamic effects. J Hypertens 1991; 9: $955-962$

31. Murohara Y, Johnston CI: Effect of neutral endopeptidase inhibition in rats with congestive heart failure. Clin Exp Pharmacol Physiol 1992; 19: 380-383

32. Cavero PG, Margulies KB, Winaver J, Seymour AA, Delaney NG, Burnett JC Jr: Cardiorenal action of neutral endopeptidase inhibition in experimental congestive heart failure. Circulation 1990; 82: 196 201

33. Napier MA, Vandlen G, Albers-Schonberg G, Nutt RF, Brady EH: Specific membrane receptors for atrial natriuretic factor in renal and vascular tissues. Proc Natl Acad Sci USA 1984; 81: 5946-5950

34. Chai SY, Sexton PM, Allen AM, Figdor R, Mendelsohn FAO: In vitro autoradiographic localization of ANP receptors in rat kidney and adrenal gland. Am J Physiol 1986; 250: F753-757

35. Maack T: Receptors of atrial natriuretic factor. Annu Rev Physiol 1992; 54: 11-27

36. Koller KJ, Goeddel DV: Molecular biology of the natriuretic peptides and their receptors. Circulation 1992; 86: $1081-1088$

37. Sonnenberg H, Honrath U, Wilson DR: In vitro microperfusion of inner medullary collecting duct in rats: effect of amiloride and ANF. Am J Physiol 1990; 259: F222-226

38. Richards M, Espiner E, Frampton C, Ikram H, Yandle T, Sopwith M, et al: Inhibition of endopeptidase EC 24.11 in humans. Hypertension 1990; 16: $269-276$

39. Erdös EG, Skidgel RA: Neutral endopeptidase 24.11 (enkephalinase) and related regulators of peptide hormones. FASEB J 1989; 3: 145 151

40. Vijayaraghavan J, Scicli AG, Carretero OA, Slaughter C, Moomaw C, Hersh LB: The hydrolysis of endothelin by neutral endopeptidase 24.11 (enkephalinase). J Biol Chem 1990; 265: 14150-14155

41. McMahon EG, Palomo MA, Moore WM, McDonald JF, Stern MK: Phosphoramidon blocks the pressor activity of porcine big endothelin-1- (1-39) in vivo and conversion of big endothelin-1- (1-39) to endothelin-1- (1-21) in vitro. Proc Natl Acad Sci USA 1991; 88: $703-707$

42. Richards AM, Wittert GA, Espiner EA, Yandle TG, Ikram H, Frampton C: Effect of inhibition of endopeptidase 24.11 on response to angiotensin II in human volunteers. Circ Res 1992; 71: $1501-$ 1507

43. Abassi ZA, Tate JE, Golomb E, Keiser HR: Role of neutral endopeptidase in the metabolism of endothelin. Hypertension 1992; 20: 8995

44. Margulies KB, Hildebrand FL Jr, Lerman A, Perrella MA, Burnett JC Jr: Increased endothelin in experimental heart failure. Circulation 1990; 82: 2226-2230 